Jurnal Teknologi, 48(E) Jun 2008: 33-47

(C) Universiti Teknologi Malaysia

\title{
PENGARUH PERSONALITI TERHADAP KEPUASAN KERJA DAN STRES KERJA GURU
}

\author{
AZLINA MOHD. KOSNIN ${ }^{1} \&$ TAN SEW LEE ${ }^{2}$
}

\begin{abstract}
Abstrak. Kajian ini bertujuan untuk mengenal pasti tret personaliti guru dan sama ada wujud pengaruh personaliti terhadap kepuasan kerja dan stres kerja guru. Di samping itu, kajian juga dijalankan untuk menentukan tahap kepuasan dan stres kerja guru serta hubungan antara dua pemboleh ubah ini. Seramai 255 orang guru dari 10 buah sekolah menengah kebangsaan di daerah Johor Bahru dipilih secara rawak sebagai responden kajian. Kajian ini dijalankan menggunakan pendekatan kuantitatif. Data dikumpul menerusi soal selidik yang diterjemahkan daripada The Big Five Inventory (BFI), Job Descriptive Index (JDI) dan Adminstrative Stress Indeks (ASI). Nilai kebolehpercayaan bagi instrumen JDI dan ASI ialah 0.91 dan 0.84. Manakala darjah kebolehpercayaan instrumen BFI ialah antara 0.73 hingga 0.80 . Para guru menyatakan bahawa tahap kepuasan kerja dan stres kerja guru secara keseluruhannya berada pada tahap yang sederhana. Dapatan kajian juga menunjukkan hubungan negatif yang signifikan antara kepuasan kerja dan stres kerja guru. Hubungan yang signifikan didapati antara dimensi-dimensi personaliti $t$ dengan kepuasan kerja dan juga stres kerja. Implikasi kajian turut dicadangkan dalam artikel ini.
\end{abstract}

Kata kunci: Personaliti; kepuasan kerja; stres kerja; guru; agreeableness; openness, conscientiousness, extraversion; neuroticism

\begin{abstract}
This study was done to determine the personality traits of teachers as well as to investigate whether these traits influence job satisfaction and stress among teachers. Another aim was to determine the level of satisfaction and stress in teaching profession and the relationship between these two variables. As many as 225 teachers from 10 national secondary schools in Johor Bahru district were chosen randomly as respondents in this study. A quantitative research approach was adopted. The Big Five Inventory (BFI), Job Descriptive Index (JDI), and Administrative Stress Index (ASI) instruments were used to measure the related variables. All items were asked in both English and Malay languages. The reliability levels of the JDI and ASI instruments were 0.91 and 0.84 respectively, while the reliability levels of the BFI subscales were between 0.73 and 0.80 . This study found that the level of job satisfaction and stress amongst the respondents as a whole was at a moderate level. Significant negative relationship in job satisfaction and stress was found in this study. Significant relationships between certain dimensions of personality $t$ and job satisfaction and stress were also found. Results are presented and discussed in detail and practical implications of the study are also suggested.
\end{abstract}

Keywords: Personality; job satisfaction; occupational stress; teacher; agreeableness; openness; conscientiousness; extraversion; neuroticism

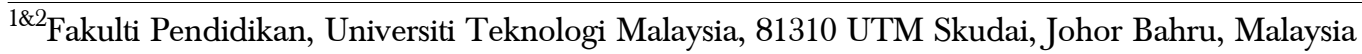




\subsection{PENGENALAN}

Kajian tentang kepuasan kerja dalam kalangan guru telah menarik perhatian para penyelidik dari pelbagai negara. Penurunan tahap kepuasan kerja para guru boleh mengakibatkan kemerosotan mutu kerja dan peningkatan kecelaruan psikologi dan stres kerja dalam kalangan guru (Troman dan Wook, 2000). Aspek-aspek ini boleh mempengaruhi semangat, motivasi dan kesanggupan guru-guru untuk memaksimumkan potensi pengajaran mereka (Schulz dan Teddlie, 1989).

Pada masa yang sama, isu stres dalam kalangan guru telah menjadi isu yang besar dan hangat dalam masyarakat (Kyriacou, 1987). Kesan negatif akibat daripada stres bukan lagi merupakan masalah peribadi yang harus ditanggung oleh pekerja itu sahaja, tetapi stres juga merupakan satu masalah kepada majikan, organisasi ataupun kerajaan serta menjejaskan kesihatan mental dan fizikal golongan ini (Chua Bee Seok, 2004). Dari segi hubungan, stres dan kepuasan kerja mempunyai hubungan timbal-balik. Dalam kerjaya perguruan, guru-guru telah melaporkan tahap stres kerja yang tinggi mengakibatkan tahap kepuasan kerja yang rendah (Galloway, et al., 1984; Kyricaou dan Sutcliffle, 1979).

Tahap profesionalisme dan integriti guru hanya dapat dipertingkatkan lagi jika mereka dapat memaksimumkan kepuasan kerja dan meminimumkan stres kerja dalam bidang kerjaya mereka. Terdapat kajian-kajian lepas yang menunjukkan kepuasan kerja dan stres berkait rapat dengan personaliti seseorang. Sebagai contoh, dalam satu kajian jangka panjang, Staw, Bell dan Clausen (1986) mendapati personaliti seseorang individu di peringkat kanak-kanak mempengaruhi kepuasan kerja mereka dalam alam pekerjaan semasa peringkat dewasa. Dapatan tersebut telah membangkitkan minat para penyelidik untuk meneruskan kajian dalam hal ini (Judge, et al., 2002). Pelbagai model dan teori telah dibentuk untuk mengkaji hubungan antara personaliti dengan kepuasan kerja (Brief, 1998 dan Motowidlo, 1996). Holand (1973) turut mencadangkan bahawa pemadanan personaliti dengan persekitaran kerja akan membawa peningkatan kepuasan dalam kerjaya yang telah dipilih oleh individu berkenaan.

Selain itu, hasil penyelidikan telah menunjukkan personaliti bukan sahaja boleh meramalkan kepuasan kerja (Brief dan Atieh, 1987; Jackson dan Schuler, 1985), tetapi juga stres kerja (Mikkelsen dan Gundersen, 2003; Motowidlo, et al., 1986). Pengaruh personaliti terhadap stres kerja dapat dilihat menerusi pelbagai model yang meletakkan personaliti sebagai peramal atau penentu utama bagi stres kerja. Model-model tersebut menjelaskan bahawa interaksi antara pelbagai tret personaliti dengan jenis pekerjaan boleh mewujudkan stres kerja (Furnham, 1992). Menurut Matthews, et al. (2003), tret personaliti mempunyai unsur genetik yang menyebabkan perbezaan individu dalam menghadapi reaksi psikologikal. Contohnya, individu yang mempunyai ciri neurotik akan bertendensi hidup dalam kesalahan mereka, mudah kecewa dan berkecenderung mengalami stres kerja serta kurang berkebolehan untuk menanganinya. 
Pelbagai definisi telah diberi kepada istilah personaliti, dan salah satu daripada takrifan yang diberi melihat personaliti sebagai tret-tret (fikiran, perasaan dan tingkah laku) yang tekal yang membezakan individu dari individu yang lain. Terdapat beberapa teori yang telah cuba menjelaskan tret-tret utama manusia, seperti teori tret Carl Jung dan Hans Eysenck. Pengkaji-pengkaji kontemporari telah mencadangkan satu teori trait yang baru menerusi dapatan dari kaedah analisis faktor, dan teori ini dikenali sebagai teori lima faktor atau 'big five' (Costa \& McCrae, 1996). Terdapat lima tret utama dalam teori ini yang dikenal dengan akronim OCEAN, iaitu keterbukaan fikiran (openness to experience), sifat sosial (extraversion), berpendapat sama dan mudah mencapai persetujuan (agreeableness), kesedaran (conscientiousness), dan gangguan emosi (neuroticism).

Kajian-kajian dari luar negara banyak dijalankan untuk meninjau sejauh mana tret-tret personaliti mempunyai hubungan dengan kepuasan kerja (contoh: Boudreau, et al., 2001; Judge, Heller dan Mount, 2002) dan stres kerja (contoh: Ahart, 2003; Cook, 2005). Kebanyakan kajian tempatan pula menumpukan hubungan antara kepuasan kerja dan stres kerja dengan persekitaran pekerjaan itu sahaja (contoh: Maheran, 2005; Mohd Kamal, 2005; Faseha, 2005; Lim, 2005; Abdul Rahim, 2002). Kajian ini telah dilakukan untuk mengkaji tahap kepuasan kerja, tahap stres kerja dan tret personaliti dalam kalangan guru sekolah menengah di daerah Johor Bahru. Kajian ini turut dilakukan untuk mengenal pasti sama ada wujud hubungan dan pengaruh yang signifikan antara tret personaliti dengan kepuasan kerja dan stres kerja khususnya dalam profesion keguruan.

\subsection{METODOLOGI}

Kajian ini berupa deskriptif tinjauan dan telah dijalankan ke atas 255 orang guru dari sekolah-sekolah menengah kebangsaan di daerah Johor Bahru. Instrumen kajian ini merupakan satu set soal selidik yang mengandungi 4 bahagian, iaitu bahagian maklumat demografi, bahagian personaliti, bahagian kepuasan kerja dan bahagian stres kerja. Instrumen yang digunakan untuk mengukur personaliti ialah 'The Big Five Inventory' (BFI) yang diperkenalkan oleh John, Donahue dan Kentle (1991). Soal selidik ini mengandungi 44 item yang mengukur 5 dimensi personaliti, iaitu Extraversion, Agreeableness, Conscientiousess, Neuroticism dan Openness. Bahagian kepuasan kerja pula diuji dengan menggunakan alat ukur Job Descriptive Index (JDI) yang dikemukakan oleh Smith, Kendall dan Hulin (1969). Alat ukur ini mengandungi 68 item yang mengukur lima aspek kepuasan kerja, iaitu kerja, gaji, kenaikan pangkat, penyeliaan dan rakan sekerja. Stres kerja pula diuji dengan menggunakan 'Administrative Stress Indeks' (ASI) yang dibina oleh Gmelch dan Swent (1982) dan telah diubah suai oleh Mazeni (2005). Alat ukur ini mengandungi 28 item yang mengukur tiga aspek, iaitu lebihan kerja, hubungan interpersonal dan persekitaran kerja. 
Semua alat ukur ini menggunakan pemeringkatan skala Likert Lima Mata. Nilai kebolehpercayaan dalaman berdasarkan Cronbach Alfa yang diuji di dalam kajian ini adalah di antara 0.73 hingga 0.80 (BFI), 0.91 (JDI) dan 0.84 (ASI). Dalam erti kata lain, semua instrumen mempunyai kebolehpercayaan dalaman yang boleh diterima kerana melebihi nilai 0.70 (McMillan dan Schumacker, 1984).

\subsection{KEPUTUSAN}

Data kajian telah dianalisis berdasarkan tujuan dan hipotesis kajian dengan menggunakan perisian komputer SPSS. Skor min digunakan untuk menentukan tahap kepuasan kerja, stres kerja serta jenis tret personaliti guru. Nilai ini kemudiannya dibandingkan dengan jadual aras bagi memudahkan interpretasi dapatan. Jadual aras ini telah ditentukan dengan membahagikan julat min (1 hingga 5) kepada tiga tahap, iaitu rendah, sederhana dan tinggi (Jadual 1). Jadual ini digunakan dalam membuat interpretasi tentang semua pemboleh ubah.

Jadual 1 Julat skor min dan aras pemboleh ubah

\begin{tabular}{cc}
\hline Julat bagi setiap kategori & Aras \\
\hline 1.00 hingga 2.33 & Rendah \\
2.34 hingga 3.67 & Sederhana \\
3.68 hingga 5.00 & Tinggi \\
\hline
\end{tabular}

Ujian Korelasi Pearson digunakan untuk menguji hubungan antara kepuasan kerja dengan stres kerja guru, dan hubungan antara personaliti dengan kepuasan kerja dan stres kerja. Untuk meninjau sejauh mana tret-tret personaliti dalam mempengaruhi kepuasan kerja dan stres kerja guru pula, ujian regresi berganda digunakan.

\subsection{Latar Belakang Responden}

Daripada 255 orang guru yang dipilih sebagai responden kajian, 43 orang guru adalah terdiri daripada guru lelaki dan 212 orang guru perempuan (Jadual 2). Dari segi kelayakan akademik tertinggi responden, didapati seorang responden berkelayakan doktor falsafah, 30 orang berkelayakan ijazah sarjana, 201 orang berkelayakan sarjana muda, 18 orang berkelayakan ijazah diploma dan 5 orang responden memiliki kelayakan yang lain. Dari segi tempoh perkhidmatan, sebanyak 77 orang responden telah mengajar dalam tempoh tiga tahun, 24 orang tiga hingga empat tahun, 72 orang responden lima hingga sepuluh tahun, 82 orang lebih daripada 10 tahun. 
Jadual 2 Latar belakang subjek kajian ( $\mathrm{N}=255$ orang)

\begin{tabular}{lcc}
\hline Pemboleh ubah & Bilangan & Peratus \\
\hline Jantina & & \\
$\quad$ Lelaki & 43 & 16.9 \\
$\quad$ Perempuan & 212 & 83.1 \\
Status Perkahwinan & & \\
$\quad$ Bujang & 57 & 22.4 \\
$\quad$ Berkahwin & 195 & 76.5 \\
Lain-lain & 3 & 1.2 \\
Kelayakan Akademik & & \\
$\quad$ Doktor Falsafah & 1 & 0.4 \\
Ijazah Sarjana & 30 & 11.8 \\
Ijazah Sarjana & 201 & 78.8 \\
Diploma & 18 & 7.1 \\
Lain-lain & 5 & 2.0 \\
Tempoh Perkhidmatan & & \\
0-3 tahun & 77 & 30.2 \\
3-4 tahun & 24 & 9.4 \\
5-10 tahun & 72 & 28.4 \\
>10 tahun & 82 & 32.2 \\
\hline
\end{tabular}

\subsection{Tahap Kepuasan Kerja Guru}

Nilai min bagi tahap kepuasan kerja secara keseluruhan ialah 3.50, iaitu pada tahap sederhana. Nilai min bagi subskala aspek kepuasan kerja guru, iaitu rakan sekerja, penyeliaan, kerja, gaji dan pangkat, masing-masing 3.90, 3.58, 3.40, 3.30, dan 2.92. Kesemua nilai min ini berada pada tahap sederhana, kecuali bagi subskala rakan sekerja yang berada pada tahap tinggi.

\subsection{Tahap Stres Kerja Guru}

Nilai min bagi tahap stres secara keseluruhan ialah 2.79, iaitu pada tahap sederhana. Nilai-nilai min bagi setiap subskala stres, iaitu lebihan kerja, persekitaran kerja dan hubungan interpersonal ialah 3.14, 3.00 dan 2.45. Kesemua nilai min ini berada pada tahap sederhana.

\subsection{Tret Personaliti Guru}

Berdasarkan maklum balas yang diperoleh, tret personaliti yang paling banyak dilaporkan dalam kalangan guru adalah tret Agreeableness dan yang paling kurang dilaporkan adalah tret Neuroticism. Nilai min bagi setiap dimensi personaliti adalah: Agreeableness ( $\mathrm{min}=3.93$, tinggi), Conscientiousness ( $\mathrm{min}=3.73$, tinggi), Extraversion $(\min =3.53$, sederhana $)$, Openness $(\min =3.37$, sederhana $)$ dan Neuroticism $(\min =$ 2.67, sederhana). 


\subsection{Hubungan Kepuasan Kerja dengan Stres Kerja}

Melalui kaedah korelasi Pearson, analisis data menunjukkan terdapat hubungan negatif yang kuat dan signifikan antara kepuasan kerja dengan stres kerja guru $(r=-0.58, p<0.01)$. Ini bermakna peningkatan tahap kepuasan kerja boleh dikaitkan dengan penurunan kadar stres dalam kalangan guru.

\subsection{Kaitan Dimensi-dimensi Personaliti dengan Kepuasan Kerja}

Ujian korelasi Pearson menunjukkan hubungan yang signifikan antara semua dimensi personaliti dengan kepuasan kerja guru, kecuali dimensi Openness (Jadual 3). Semua nilai korelasi yang signifikan ini adalah positif kecuali bagi tret Neuroticism. Semua nilai $r$ berada pada aras sederhana.

Ujian regresi berganda turut dilaksanakan untuk menentukan pengaruh personaliti terhadap kepuasan kerja. Hasil analisis mendapati personaliti dapat meramal sebanyak $21 \%$ kepuasan kerja guru, dan tiga daripada lima dimensi personaliti telah didapati mempunyai sumbangan yang signifikan terhadap kepuasan kerja guru. Dapatan ujian adalah seperti di Jadual 4.

Dimensi Agreeableness dan Extraversion didapati memberikan sumbangan yang positif terhadap kepuasan kerja dengan nilai $\beta=0.29$ dan 0.15. Dimensi Neuroticism

Jadual 3 Hubungan antara dimensi personaliti dengan kepuasan kerja-kerja guru

\begin{tabular}{lcc}
\hline Dimensi Personaliti & Nilai Korelasi & Aras Signifikan p \\
\hline Extraversion & $0.23^{*}$ & 0.00 \\
Neuroticism & $-0.36^{*}$ & 0.00 \\
Agreeableness & $0.37^{*}$ & 0.00 \\
Conscientiousness & $0.22^{*}$ & 0.00 \\
Openness & 0.11 & 0.09 \\
\hline
\end{tabular}

*Korelasi adalah signifikan pada paras signifikan $\alpha=0.01$ (ujian 2 hujung)

Jumlah responden $=255$. Pemboleh ubah bersandar $=$ kepuasan kerja.

Jadual 4 Pemboleh ubah peramal dimensi-dimensi personaliti bagi kepuasan kerja guru

\begin{tabular}{lccc}
\hline Pemboleh Ubah Peramal & \multicolumn{3}{c}{ Kepuasan Kerja } \\
& Beta Piawai & t & p \\
\hline Agreeableness & 0.29 & 4.75 & 0.00 \\
Conscientiousness & -0.05 & -0.77 & 0.44 \\
Extraversion & 0.15 & 2.44 & 0.02 \\
Neuroticism & -0.27 & -4.18 & 0.00 \\
Openness & -0.06 & -0.95 & 0.35 \\
$\mathrm{R}$ berganda $=0.22$ & $\mathrm{R}^{2}$ diselaraskan $=0.21$ & \\
$\mathrm{~F}=14.34$ & $\mathrm{df}=5,249$ & $\mathrm{p}<0.000$ \\
\hline
\end{tabular}


juga mempunyai pengaruh yang signifikan terhadap kepuasan kerja, tetapi nilai betanya adalah negatif $(\beta=-0.27)$. Semua nilai beta adalah signifikan sekurangkurangnya pada aras $p<0.05$. Dimensi Conscientiousness dan Openness tidak mempunyai sumbangan yang signifikan terhadap kepuasan kerja.

\subsection{Kaitan Dimensi Personaliti dengan Stres Kerja}

Kaedah analisis yang sama (korelasi Pearson dan regrasi berganda) telah digunakan untuk menguji kaitan antara dimensi personaliti dengan stres kerja. Melalui analisis korelasi Pearson, dimensi Neuroticism dan Agreeableness didapati mempunyai korelasi yang sederhana dan signifikan dengan stres kerja. Walau bagaimanapun, kaitan ini adalah negatif bagi dimensi Agreeableness dan positif bagi dimensi Neuroticism (Jadual 5).

Melalui analisis regresi berganda, dimensi personaliti didapati hanya boleh menjelaskan sebanyak 9\% daripada varian stres kerja, dan didapati 2 daripada 5 dimensi personaliti memberi sumbangan yang signifikan. Dimensi Neuroticism didapati memberikan sumbangan yang tertinggi dengan nilai $\beta=0.23$ dan dimensi Agreeableness pula memberi nilai $\beta=-0.21$. Kedua-dua nilai adalah signifikan pada aras $p<0.001$ (Jadual 6).

Jadual 5 Hubungan antara dimensi personaliti dengan stres kerja guru

\begin{tabular}{lcc}
\hline Dimensi Personaliti & Nilai Korelasi & Aras Signifikan p \\
\hline Extraversion & -0.11 & 0.07 \\
Neuroticism & $0.25^{*}$ & 0.00 \\
Agreeableness & $-0.25^{*}$ & 0.00 \\
Conscientiousness & -0.10 & 0.10 \\
Openness & -0.03 & 0.69 \\
\hline
\end{tabular}

*Korelasi adalah signifikan pada paras signifikan $\alpha=0.01$ (ujian 2 hujung)

Jumlah responden $=255$. Pemboleh ubah bersandar $=$ kepuasan kerja.

Jadual 6 Pemboleh ubah peramal dimensi-dimensi personaliti bagi stres kerja guru

\begin{tabular}{lccc}
\hline Pemboleh Ubah Peramal & \multicolumn{3}{c}{ Stres Kerja } \\
& Beta Piawai & $\mathbf{t}$ & p \\
\hline Agreeableness & -0.21 & -3.13 & 0.00 \\
Conscientiousness & 0.08 & 1.03 & 0.31 \\
Extraversion & -0.07 & -1.03 & 0.30 \\
Neuroticism & 0.23 & 3.22 & 0.00 \\
Openness & 0.08 & 1.11 & 0.27 \\
$\mathrm{R}$ berganda $=0.11$ & $\mathrm{R}^{2}$ diselaraskan $=0.09$ & \\
$\mathrm{~F}=5.83$ & $\mathrm{df}=5,249$ & $\mathrm{p}<0.000$ \\
\hline
\end{tabular}


Ini menunjukkan bahawa dimensi Neuroticism dan dimensi Agreeableness merupakan peramal terbaik bagi stres kerja. Manakala dimensi Conscientiousness, Extraversion dan Openness bukan peramal yang baik kerana ketiga-tiga dimensi tersebut tidak memberikan sumbangan yang signifikan.

\subsection{PERBINCANGAN}

\subsection{Tahap dan Aspek Dominan Kepuasan Kerja Guru}

Dapatan kajian menunjukkan tahap kepuasan kerja responden pada keseluruhannya berada pada tahap yang sederhana. Hanya satu aspek sahaja, iaitu aspek rakan sekerja menunjukkan skor min yang tinggi.

Dapatan ini selari dengan beberapa dapatan kajian lalu. Sebagai contoh, Lim (2005) dalam kajiannya terhadap guru-guru teknikal menunjukkan tahap kepuasan kerja guru yang sederhana. Kajian yang telah dilakukan oleh Faseha (2005) pula menyamai dapatan kajian ini. Faseha turut mendapati aspek rakan sekerja mencecah tahap kepuasan kerja tertinggi sementara aspek gaji dan dimensi kenaikan pangkat mempunyai tahap kepuasan kerja sederhana. Kedua-dua Lim (2005) dan Faseha (2005) turut mendapati responden dalam kajian-kajian mereka menyatakan bahawa peluang kenaikan pangkat dalam bidang perguruan amatlah kurang.

\subsection{Tahap dan Aspek Dominan Stres Kerja Guru}

Hasil kajian menunjukkan tahap stres kerja responden pada keseluruhannya berada pada tahap yang sederhana. Berkenaan subskala stres guru pula, kajian ini mendapati bahawa min skor responden bagi aspek lebihan kerja, persekitaran kerja dan hubungan interpersonal juga berada pada tahap sederhana. Aspek stres kerja yang paling dominan bagi responden kajian ini adalah lebihan kerja. Dapatan ini selaras dengan kajian-kajian lepas sama ada di luar mahupun di dalam negeri (Flowers, 2003; Wilson, 2002; Noor Hadayah, 2003; Shahrina, 2005). Kajian-kajian tersebut menyatakan bahawa bebanan tugas merupakan salah satu faktor utama yang menyumbang kepada stres kerja guru.

Antara item yang mendapat respon tertinggi dalam kalangan guru dalam kajian ini adalah masa yang diberi tidak mencukupi untuk menyiapkan sesuatu tugas, terlalu banyak kerja dalam sesuatu masa, tiada masa untuk persediaan mengajar, selalu mengambil alih tugas guru yang tidak hadir dan sering mendapat tugas yang tidak sepadan dengan kehendak diri sendiri.

Dalam aspek persekitaran kerja pula, responden menyatakan alat kelengkapan pejabat yang tidak berfungsi dengan betul, keadaan kelas atau bilik guru yang terlalu padat ada kalanya mengganggu pengajaran guru. Keadaan tempat kerja yang tidak selesa telah menyebabkan stres kerja dalam kalangan guru (Kyricaou dan Sutcliffe, 2001). Boyle, et al. (1995) dalam model stres kerja guru menunjukkan bahawa salah satu faktor stres ialah hubungan interpersonal. Hubungan ini adalah penting untuk 
membina jaringan sokongan yang baik antara guru-guru di sekolah demi kepentingan dan pembangunan komuniti bersama. Dalam kajian ini, hubungan interpersonal yang baik dalam kalangan guru telah menyumbang kepada tahap stres yang sederhana dan seterusnya mencapai min paling rendah antara tiga aspek stres kerja.

\subsection{Dimensi Dominan Personaliti Guru}

Hasil kajian menunjukkan min skor Agreeableness dan Conscientiousness berada pada tahap tinggi, manakala dimensi Extraversion, Openness dan Neuroticism pula berada pada tahap sederhana. Dapatan ini menjelaskan bahawa guru-guru tidak suka mencari kesalahan orang lain, tidak memulakan pertengkaran dengan orang lain, bertimbang rasa dan baik hati, suka bekerjasama, memiliki naluri memaafkan orang lain secara semula jadi, bersopan santun, suka membantu dan tidak mementingkan diri sendiri. Ciri-ciri seumpama ini selaras dengan dapatan kajian Perlman dan McCann (1998) tentang "Student Pet Peeves about Teaching," iaitu seseorang guru yang mempunyai dimensi Agreeableness tinggi akan sentiasa mempunyai hubungan antara guru dan pelajar yang mesra, mengingati nama pelajar dan memanggilnya apabila ada peluang, bersifat liberal dan fleksibel semasa pengajaran dan pembelajaran.

Hasil dapatan juga menunjukkan guru-guru mempunyai dimensi Conscientiousness yang tinggi. Para responden menyatakan bahawa mereka merupakan pekerja yang boleh dipercayai, bersungguh-sungguh sehingga tugasan diselesaikan, buat kerja dengan teliti, tidak malas, membuat perancangan dan melaksanakannya, membuat kerja dengan cekap, teratur, tidak mudah terganggu atau hilang tumpuan. Sesungguhnya, seseorang guru yang mempunyai dimensi Conscientiousness yang tinggi akan sentiasa membuat persediaan mengajar yang rapi, rancangan pengajaran yang pelbagai dan bersistematik dalam persediaan bahan peperiksaan (Perlman dan McCann, 1998). Bagi dimensi Extraversion, sifat-sifat responden seperti bersemangat tinggi, bertenaga, suka bergaul dan bersosial, dan personaliti yang tegas masih berada pada tahap sederhana. Perlman dan McCann (1988) menyatakan bahawa guru yang mempunyai skor yang tinggi dalam dimensi ini adalah berinisiatif untuk mempertingkat komunikasi dan berkeupayaan menjalankan pengajarannya dengan menarik, aktif serta merangsangkan.

Responden kajian ini memiliki dimensi Openness yang hanya berada pada tahap sederhana. Dalam erti kata lain, mereka kurang berinisiatif untuk mencari pengalaman, kurang bersifat ingin tahu tentang perkara yang berlainan dan tidak berfikiran luas. Bagi tret Neuroticism, walaupun nilai skor minnya $=2.67$ iaitu berada dalam lingkungan tahap sederhana, sebenarnya nilai ini lebih menghampiri lingkungan tahap rendah. Kebanyakan responden kajian menyatakan sifat-sifat seperti mudah rasa gementar, tertekan, dan kerap risau. Walau bagaimanapun, pada masa yang sama mereka juga merupakan guru yang bersifat tenang, menangani tekanan dengan baik, emosi yang stabil, tidak mudah berasa kecil hati dan tenang dalam keadaan yang tegang. 


\subsection{Hubungan antara Kepuasan Kerja dengan Stres Kerja Guru}

Secara keseluruhannya, hasil kajian menunjukkan bahawa terdapat hubungan negatif sederhana tinggi $(r=-0.58)$ antara kepuasan kerja dan stres kerja. Keputusan ini menyamai dapatan kajian-kajian lepas (contoh: Konert, 1997; Lim, 2005) yang mendapati hubungan negatif antara stres kerja dan kepuasan kerja.

\subsection{Hubungan antara Tret-tret Personaliti dengan Kepuasan Kerja Guru}

Dari segi hubungan tret personaliti dengan kepuasan kerja, dapatan kajian menunjukkan empat daripada lima tret personaliti (iaitu agreeableness, extraversion, conscientiousness dan neuroticism) mempunyai hubungan yang signifikan dengan kepuasan kerja. Semua hubungan ini adalah positif kecuali hubungan antara tret neuroticism dengan kepuasan kerja. Dapatan kajian ini selaras dengan dapatan kajiankajian lepas yang menunjukkan bahawa terdapat hubungan yang signifikan antara kepuasan kerja dengan personaliti guru (Boudreau, et al., 2001; Judge, et al., 2002).

Kaitan antara tret personaliti dan kepuasan kerja ini boleh dilihat melalui ciri-ciri yang selari dengan ciri-ciri guru yang baik. Tret agreeableness yang mengandungi ciri-ciri seperti baik hati, bersopan-santun, peramah, bersimpati, bekerjasama dan seronok didekati membolehkan guru mencapai kepuasan dalam kerjanya. Manakala ciri-ciri dalam tret extraversion seperti bersemangat tinggi, bertenaga, suka bergaul dan bersosial diperlukan oleh seseorang guru apabila berhadapan dengan cabarncabaran dalam dunia pendidikan supaya dapat berfungsi dengan cekap dan berketrampilan.

Selain itu, guru-guru yang mempunyai tret conscientiousness mempunyai ciri-ciri seperti berdikari, tersusun, boleh dipercayai, bertanggungjawab, konsisten dan bekerja keras. Personlaiti ini membolehkan menghadapi cabaran pendidikan seperti permasalahan sosial, kemerosotan kerohanian dan tuntutan masyarakat. Akhir sekali, guru yang rendah dalam tret neuroticism mempunyai kestabilan emosi dan tenang mampu menghadapi cabaran permasalah sosial seperti ponteng sekolah, melawan guru, merokok dan sebagainya. Suasana kerja yang menyeronokkan, kreatif dan menyihatkan serta memiliki persepsi positif membolehkan para guru mengecapi kepuasan kerja.

\subsection{Hubungan antara Tret-tret Personaliti dengan Stres Kerja Guru}

Dari segi hubungan tret personaliti dengan stres kerja, dapatan menunjukkan hanya tret agreeableness dan tret neuroticism mempunyai hubungan yang signifikan dengan stres kerja. Guru yang tinggi dalam tret agreeableness mempunyai ketahanan yang 
tinggi terhadap stres kerja, manakala guru yang tinggi dalam tret neuroticism pula mudah mengalami stres kerja yang tinggi. Menurut McAdams (2005), individu yang memiliki tret agreeableness yang tinggi akan lebih senang untuk menyayangi orang lain. Sifat tersebut membolehkan stres kerja yang dihadapi dipersepsikan ke tahap yang minimum. Manakala, guru yang tinggi dalam tret neuroticism pula tidak mampu bertoleransi dengan stres kerja dan penyesuaian keperluan profesion perguruan. Tret neuroticism didapati mempengaruhi persepsi seorang individu terhadap stres kerja melalui tanggapan negatif (Cooper \& Payne, 1988).

\subsection{Pengaruh Tret Personaliti terhadap Kepuasan Kerja dan Stres Kerja Guru}

Berdasarkan ujian regresi berganda, dapatan menunjukkan hanya tret agreeablenes dan tret neuroticism mempunyai pengaruh terhadap kepuasan kerja dan stres kerja subjek. Dalam kajian ini, sebab utama tret agreeablenes dan tret neuroticism dapat digunakan untuk meramal kepuasan kerja dan stres kerja guru adalah kerana keduadua tret tersebut memperoleh skor korelasi yang tertinggi dengan kepuasan dan stres kerja berbanding dengan tret extraversion, conscientiousness dan openness.

Sebab-sebab lain yang membawa kepada tret agreeablenes sebagai peramal kepada kepuasan dan stres kerja adalah berdasarkan beberapa sifatnya:

(i) Tret agreeablenes berkorelasi dengan "pro-social motives" yang bertujuan untuk mendapatkan hasil yang baik untuk diri dan orang lain (Beersma dan De Dreu, 2002).

(ii) Tret ini memandu kepada "the need for affiliation," iaitu tingkah laku dan pemikiran individu tersebut mementingkan hubungan afektif yang positif (Atkinson, et al., 1954).

(iii) Tret agreeablenes berkorelasi dengan "the need for intimacy," iaitu keinginan untuk mewujudkan corak perhubungan yang rapat dan interaksi atau komunikasi yang kerap dengan orang lain. Golongan yang mempunyai ciri agreeablenes adalah boleh dipercayai, bekerjasama, bertimbang rasa dan "moved by others"(Costa dan McCrae, 1992).

(iv) Hubungan harmonis yang dipersepsikan menggalakkan mereka membuat artibusi yang positif (Graziano et al., 1996) dan berkecenderungan meminimumkan kesan negatif dalam sebarang konflik (Kinnunen $e t$ al., 2003).

Ciri-ciri agreeablenes seperti di atas menyebabkan guru-guru tersebut berasa puas hati dengan rakan sekerja, penyeliaan, suasana kerja, gaji, pangkat dan lain-lain aspek yang berkaitan dengan kepuasan kerja. Mereka juga boleh bertoleransi dengan stres yang mungkin dihadapi dalam aspek lebihan kerja, persekitaran kerja dan juga hubungan interpersonal di sekolah. 
Bagi tret Neuroticism pula, kajian-kajian lepas (Cook, 2005; Boudreau, et al., 2001; Brief dan Atieh, 1987) menunjukkan bahawa tret kestabilan emosi atau neuroticism yang rendah mempunyai hubungan korelasi yang paling tinggi dan merupakan peramal terbaik terhadap kepuasan kerja. Tret neuroticism sebagai peramal kepada kepuasan kerja dan stres kerja guru adalah berdasarkan beberapa ciri berikut:

(i) Kecenderungan melihat aspek negatif tugasan menyebabkan guru-guru ini kurang berjaya dalam kerjaya dan kurang mengalami kepuasan kerja. Proses kognitif mereka berasaskan persepsi negatif, iaitu memfokus dan mengingati aspek-aspek yang negatif. Semakin banyak ingatan negatif, maka gangguan terhadap pencapaian kerjanya akan bertambah untuk menjadikan guru tersebut kurang mengalami kepuasan kerja (Larsen, 1992).

(ii) Mereka cenderung berasa takut dan bimbang. Emosi-emosi negatif tersebut seterusnya mengelakkan diri daripada menanggung tugasan kerjayanya, maka peluang mengalami kepuasan kerja juga akan berkurangan. Keadaan ini juga dikaitkan dengan aspek efikasi kendiri yang rendah dengan jangkaan bahawa mereka akan gagal dalam pelbagai tugasan. Akibatnya mereka akan memilih jenis tugasan yang kurang memberikan kepuasan (jenis yang kurang autonomi, rutin kurang identiti, tidak penting dan senang untuk dilaksanakan) sesuai dengan sifat mereka yang kurang mementingkan pencapaian kerjaya (Costa dan McCrae, 1988).

(iii) Senang dipengaruhi oleh kebimbangan dan stres serta tidak boleh berfungsi secara efektif. Mereka tidak dapat mengendalikan stres kerja yang biasa berlaku dan seterusnya mempengaruhi keupayaan untuk menunjukkan prestasi yang baik (Judge dan Bono, 2001). Emosi mereka yang kurang stabil akan mempengaruhi pencapaian dan prestasi kerja serta mudah mengalami stres kerja.

Penerangan di atas menunjukkan bahawa guru-guru yang mempunyai tret neuroticism rendah mempunyai emosi yang stabil dan lebih berkeyakinan serta bersikap positif terhadap apa-apa cabaran dalam kerjaya profesionnya. Malah, menurut Bolger (1990), tret neuroticism juga dapat mempengaruhi strategi menangani stres. Sebagai rumusannya, dapatlah diperkatakan tret neuroticism dan agreeablene boleh digunakan untuk meramalkan kepuasan kerja dan stres kerja dalam kalangan guru.

\subsection{KESIMPULAN}

Profil kepuasan kerja dan stres kerja dan tret personaliti guru telah dikenal pasti dalam kajian ini. Dapatan kajian ini boleh digunakan sebagai garis panduan bagi pihak-pihak tertentu seperti Kementerian Pelajaran dalam merangka strategi, pendekatan dan program yang lebih berkesan untuk guru-guru. 
Pihak yang terlibat dalam penggubalan, pelaksanaan dan penilaian pendidikan perlu menitikberatkan aspek personaliti, kepuasan kerja dan stres kerja untuk mewujudkan barisan guru yang bersedia dalam menghadapi pelbagai bentuk perubahan, cabaran, isu, permasalahan dan konflik supaya mampu bergerak seiring dengan peredaran serta tuntutan semasa dunia pendidikan.

Salah satu asas kepada kejayaan dalam pendidikan adalah personaliti guru kerana aspek ini merupakan asas struktur pendidikan yang kukuh. Usaha pihak Kementerian Pelajaran menjalankan ujian personaliti dalam memilih bakal guru amat disokong dan perlu diteruskan bagi memastikan guru-guru yang terpilih mempunyai ciri-ciri personaliti guru yang cemerlang. Ujian personaliti mungkin juga boleh diberikan kepada guru-guru yang sedia ada agar mereka lebih memahami diri sendiri dan dapat berusaha untuk memperbaiki diri.

Walaupun personaliti guru mempunyai kaitan dengan kepuasan kerja serta tahap stress guru, keupayaannya untuk meramalkan faktor-faktor ini adalah rendah. Kebajikan guru perlu juga dipantau dan dilindungi agar mereka dapat menjalankan tugas mereka dengan baik. Pada dasarnya tahap kepuasan kerja serta stres guru berada pada tahap sederhana. Akan tetapi, perincian dapatan ini menyarankan agar faktor beban kerja serta peluangkenaikan pangkat guru perlu dikaji memandangkan aspek-aspek ini mendapat skor terendah yang menghampiri tahap rendah.

\section{RUJUKAN}

Ab. Rahim Aris. 2002. Kajian ke atas Faktor-faktor yang Mempengaruhi Stres (Tekanan) dan Niat untuk Meninggalkan Profesion Pergunaan di kalangan Guru Sekolah Menengah dan Sekolah Rendah di Daerah Kota Tinggi Johor.Universiti Teknologi Malaysia: Tesis Sarjana.

Ahart, A. M. 2003. Determining the Student Behaviors Contributing to Teacher Stress and the Relationship between these Behaviors and Teacher Characteristics. University of Minnesota: A Doctorial Dissertation.

Atkinson, T. W., R. W. Hesyns dan J. Veroff. 1954. The Effect of Experimental Arousal of the Affiliation Motive on Thematic Apperception. In Dijkstra, M. T. M.

Dierendonck, A. E. dan C. K. W. De Dreu. 2004. Conflict and Well-Being at Work: The Moderating Role of Personality. Emeralds Database. Tarikh capaian: 24 April 2006.

Beersma, B. dan C. K. W. De Dreu. 2002. Integrative and Distributive Negotiation in Small Groups: Effects of Task Structure, Decision Rule, and Social Motive. In Dijkstra, M. T. M., Dierendonck, A. E., De Dreu, C. K. W. 2004. Conflict and Well-Being at Work: The Moderating Role of Personality. Emeralds database. Tarikh capaian: 24 April 2006.

Bolger, N. 1990. Coping as a Personality Process: A Prospetcive Study. Journal of Social Psychology. 59: 525-537.

Boudreau, J. W., W. R. Boswell, T. A. Judge dan R. D. Bretz. 2001. Personality and Cognitive Ability as Predictors of Job Search among Employed Managers. Personnel Psychology. 54(1): 25-50.

Boyle, G. J., Borg, M. G., Falzan. J. M. dan A. J. Baglioni Jr. 1995. A Structural Model of Tretons of Teacher Stress. British Journal of Educational Psychology. 65: 49-67.

Brief, A. P. 1998. Attitudes in and Around Organizations. Thousand Oaks, CA: Sage Publications.

Brief, A. P. dan J. M. Atieh. 1987. Studying Job Stress: Are we Making Mountains out of Molehills? Journal of Occupational Behaviour. 8(2): 115-126.

Chua Bee Seok. 2004. Stres Pekerjaan, Kepuasan Kerja, Kesihatan Mental dan Kesihatan Fizikal di kalangan Guru Sekolah Menengah, Kota Kinabalu, Sabah. Jurnal Teknologi. 40(E) Jun: 1-18. 
Cook, V. D. 2005. An Investigation of the Construct Validity of the Big Five Construct of Emotional Stability in Relation to Job Performance, Job Satisfaction, and Career Satisfaction. University of Tennessee: A Doctorial Dissertation.

Costa, P. T. dan R. R. McCrae. 1988. Personality in Adulthood: A Six-Year Longitudinal Study of Self-Reports and Spouse Ratings on the NEO Personality Inventory. Journal of Personality and Social Psychology. 54(5): 853-863.

Costa, P. T. dan R. R. McCrae. 1992. Four Ways Five Factors are Basic. Personality and Individual Differences. 13(6): 653-666.

McCrae, R. R. dan P. T. Costa Jr. 1996. Toward a New Generation of Personality Theories: Theoretical Contexts for the Five-factor Model. In J. S. Wiggins (Ed.), The Five-factor Model of Personality: Theoretical Perspectives. New York: Guilford. 51-87.

Faseha Bt. Jelani. 2005. Hubungan Kepuasan Kerja dengan Kecenderungan hendak Berhenti Kerja: Satu Tinjauan di kalangan Guru-Guru Agama di Sekolah Menengah Daerah Muar. Universiti Teknologi Malaysia: Tesis Sarjana.

Flowers, T. T. 2003. Why do Public School Teachers Leave their Profession. A Capela University, Minneapolis: A Doctorial Dissertation.

Furnham, A. 1992. Personality at Work: The Role of Individual Differences in the Workplace. London: Routledge.

Galloway, D., K. Boswell, F. Panckhurst, C. Baswell dan K. Green. 1984. Sources of Satisfaction and Dissatisfaction for New Zealand School Teachers. Educational Research. 27(1): 44-51.

Graziano, W. G., L. A. Jensen-Campbell dan E. C. Hair. 1996. Perceiving Interpersonal Conflict and Reacting to it: The Case of Agreeableness. In Dijkstra, M. T. M.

Dierendonck, A. E. dan C. K. W. De Dreu. 2004. Conflict and Well-Being at Work: The Moderating Role of Personality. Emeralds database. Tarikh capaian: 24 April 2006.

Holland, J. L. 1973. Making a Vocational Choice: A Theory of Personalities Type and Model Environment. Englewood Cliffs, New Jersey: Prentice Hall.

Jackson, S. E. dan R. S. Schuler. 1985. A Meta-Analysis and Conceptual Critique of Research on Role Ambiguity and Role Conflict in Work Settings. Organizational Behavior and Human Decision Processes. 36(1): 16-78.

John, O. P., E. M. Donahue dan R. L. Kentle. 1991. The "Big Five" Inventory: Version 4a and 54. Technical Report. Berkeley, CA: Institute of Personality and Social Research, University of California.

Judge, T. A. dan J. E. Bono. 2001. Relationship of Core Self-Evaluation Trets - Self -Esteem, Generalized Self Efficacy, Locus of Control, and Emotional Stability -With Job Satisfaction and Performance: A Meta Analysis. Journal of Applied Psychology. 86: 80-92.

Judge, T. A., D. Heller dan M. K. Mount. 2002. Five-factor Model of Personality and Job Satisfaction: A metaanalysis. Journal of Applied Psychology. 87(3): 530-541.

Kinnunen, U., A. Vermulst, J. Gerris dan Makikangas. 2003. Work-Family Conflict and its Relations to WellBeing: The Role of Personality as a Moderating Factors. In Dijkstra, M. T. M., Dierendonck, A. E., \& De Dreu, C. K. W. 2004. Conflict and Well-Being at Work: The Moderating Role of Personality. Emeralds Database. Tarikh capaian: 24 April 2006.

Konert Ewa 1997. The Relationship among Middle-School Teacher Burnout, Stress, Job Satisfaction and Coping Styles. Wayne State University: A Doctorial Dissertation.

Kyriacou, C. 1987. Teachers Stress and Burnout: An International Review. Educational Research. 29(2): $146-152$.

Kyriacou, C. dan J. Sutcliffle. 1979. Teacher Stress and Satisfaction. Education Research. 21: 89-96.

Larsen, R. J. 1992. Neuroticism and Selective Encoding and Recall of Symptoms: Evidence from a Combined Concurrent- Retrospective Study. Journal of Personality and Social Psychology. 62: 486-488.

Lim Yee Chian. 2005. Hubungan di antara Stres Kerja dengan Kepuasan Kerja di kalangan Guru Teknikal di Sekolah Menengah Teknik, di Negeri Kedah Darul Aman. Universiti Teknologi Malaysia: Tesis Sarjana.

Maheran@ Malek Bin Ahmad Johari. 2005. Stres dan Kepuasan Kerja di kalangan Guru Sekolah Menengah Daerah Tangkak, Negeri Johor Darul Takzim. Universiti Teknologi Malaysia: Tesis Sarjana.

Mazeni Bt Ismail. 2005. Faktor-Faktor yang Mempengaruhi Stres di Kalangan Guru Sekolah Menengah di Empat Buah Negeri. Universiti Teknologi Malaysia: Tesis Sarjana.

Matthews, G., I. J. Deary dan M. C. Whiteman. 2003. Personality Trets. United Kingdom: Cambridge University Press.

McAdams. D. P. 2005. The Person: A Nerw Introduction to Personality Psychology. 4th ed. Hoboken, N J: John Wiley \& Sons. 
McMillan, J. H. dan S. Schumacker. 1984. Research in Education: A Conceptual Introduction. Canada: Little Brown Co.

Mikkelsen, A. dan Gundersen, M. 2003. The Effect of a Participatory Organizational Intervention on Work Environment, Job Stress, and Subjective Health Complaints. International Journal of Stress Management. 10(2): 91-110.

Mohd Kamal Bin Ahmad Untong. 2005. Kepuasan Kerja di Kalangan Guru-Guru di Daerah Kluang, Johor. Universiti Teknologi Malaysia: Tesis Sarjana.

Motowidlo, S.J. 1996. Orientation toward the Job and Organization. In K. R. Murphy. Ed. Individual Differences and Behavior in Organizations. San Francisco: Jossey Bass. 175-208.

Motowidlo, S., J. Packard dan M. Marning. 1986. Occupational Stress: Its Causes and Consequences for Job Performance. Journal of Applied Psychology. 71: 618-629.

Perlman dan McCann. 1998. Student Pet Peeves about Teaching. In Kantonitz, B. H., Roediger III, H. L., \& Elmes, D. G. 2005. Experimental Psychology. $8^{\text {th }}$ ed. Belmont, CA: Thomsons Learning, Inc.

Shahrina Bt Ismail 2005. Stres Kerja di kalangan Guru-guru Sekolah Menengah di Zon PKG Parit Bunga, Muar, Johor. Universiti Teknologi Malaysia: Tesis Sarjana.

Staw, B. M., N. E. Bell dan J. A. Clausen. 1986. The Dispositional Approach to Job Attitudes: A Lifetime Longitudinal Test. In Judge, T. A. \& J. E. Bono \& E. A. Locke. (2000). Personality and Job Satisfaction: The Mediating Role of Job Characteristics. Journal of Applied Psychology. 85(2): 237-249.

Wilson, V. 2002. Feeling the Strain: An Overview of the Literature on Teachers' Stress. University Glasgow: The Scottish Council for Research in Education. 